\title{
Author Correction: Murine liver repair via transient activation of regenerative pathways in hepatocytes using lipid nanoparticle-complexed nucleoside- modified mRNA
}

Fatima Rizvi (1), Elissa Everton (1D), Anna R. Smith (1), Hua Liu, Elizabeth Osota, Mitchell Beattie, Ying Tam, Norbert Pardi, Drew Weissman \& Valerie Gouon-Evans (B)

Correction to: Nature Communications https://doi.org/10.1038/s41467-021-20903-3, published online 27 January 2021.

In the original version of the published article, the Acknowledgements section was missing a statement to acknowledge funding from an Alpha-1 Foundation Research grant. The correct Acknowledgements paragraph is:

Published online: 10 May 2021

\section{Acknowledgements}

This work was supported by the March of Dimes Research Grant \#6-FY14-530, NIH NIDDK R01DK124361-01A1, and the Alpha-1 Foundation Research Grant ID614163. We are grateful to Brian R. Tilton of the BUSM Flow Cytometry Core for technical assistance, supported by NIH Grant 1UL1TR001430, and Drs. Greg Miller and Marianne James of the CReM, supported by grants R24HL123828 and U01TR001810. Dr. Hua Liu, Elissa Everton and Anna Rose Smith are supported by the TL1TR001410 award.

This has now been corrected both in the HTML and the PDF versions of the article.

(c) (i) Open Access This article is licensed under a Creative Commons Attribution 4.0 International License, which permits use, sharing, adaptation, distribution and reproduction in any medium or format, as long as you give appropriate credit to the original author(s) and the source, provide a link to the Creative Commons license, and indicate if changes were made. The images or other third party material in this article are included in the article's Creative Commons license, unless indicated otherwise in a credit line to the material. If material is not included in the article's Creative Commons license and your intended use is not permitted by statutory regulation or exceeds the permitted use, you will need to obtain permission directly from the copyright holder. To view a copy of this license, visit http://creativecommons.org/licenses/by/4.0/.

(c) The Author(s) 2021 